\title{
PENGARUH PERCEIVED PARENTAL REWARD, ENTREPRENEURIAL SELF EFFICACY, YANG DIMODERASI FAMILY BUSINESS INVOLVEMENT TERHADAP ENTREPRENEURIAL INTENTION DI UNIVERSITAS PELITA HARAPAN
}

\author{
Zoel Hutabarat ${ }^{1 *}$, Denny Larson ${ }^{2}$, Marchel Denny Irawan ${ }^{3}$ \\ ${ }^{123}$ Universitas Pelita Harapan, Tangerang, Indonesia \\ M.H. Thamrin Boulevard 1100, Klp. Dua, Kec. Klp. Dua, Kota Tangerang, Banten 15811 \\ 1*zoel.hutabarat@uph.edu, ${ }^{2}$ DL5642@ student.uph.edu, ${ }^{3}$ MI404@ student.uph.edu
}

\begin{abstract}
Abstrak
Jumlah pelaku bisnis yang memulai dari bisnis keluarga di Indonesia cukup banyak. Namun jumlah perusahaan yang menyiapkan penerus untuk melanjutkan dan mengembangkan bisnis keluarga bisa dihitung dengan jari. Penelitian ini bertujuan untuk mengetahui pengaruh Perceived Parental Reward, Entrepreneurial Self-Efficacy yang dimoderatori oleh Family Business Involvement terhadap Entrepreneurial Intention. Penelitian ini menggunakan penelitian kuantitatif dengan menyebarkan 200 pertanyaan dan diuji menggunakan PLS Structural Equation Modeling (SEM) untuk mengevaluasi reliabilitas dan validitas model pengukuran dan model struktural. Hasil penelitian menunjukkan bahwa terdapat pengaruh positif antara Perceived Parental Reward, Entrepreneurial Self-Efficacy yang dimoderatori oleh Family Business Involvement terhadap Entrepreneurial Intention. Dari hasil tersebut diharapkan kampus dapat membentuk lingkungan yang mendukung bagi pengembangan usaha keluarga. Tidak selalu membentuk pola pikir untuk membentuk usaha baru agar usaha keluarga yang sedang berkembang tidak terbengkalai atau tidak mau lagi membangun usaha keluarga.
\end{abstract}

Kata kunci: Persepsi penghargaan kewirausahaan orang tua, self-efficacy kewirausahaan, keterlibatan bisnis keluarga, niat kewirausahaan.

\begin{abstract}
The number of business people who started from a family business in Indonesia was quite large. But the number of companies that prepare successors to continue and develop the family buiness could be counted on fingers. This study aimed to determine the effect of Perceived Parental Reward, Entrepreneurial Self Efficacy, which was moderated by Family Business Involvement on Entrepreneurial Intention. This study used quan-titative research by distributing 200 questionnaires and tested using PLS Structural Equation Modeling (SEM) to evaluate the reliability and validity of measurement models and structural models. The results showed that there was a positive influence between the Perceived Parental Reward, Entrepreneurial Self Efficacy, which was moderated by Family Business Involvement on Entrepreneurial Intention. From these results, it was hoped that the campus could form a supportive environment for the development of family businesses. It did not always form the mindset to form a new business so that a growing family business was not abandoned or no longer want to build a family business.

Keywords: Perceived parental entrepreneurial reward, entrepreneurial self-efficacy, family business involvement, entrepreneurial intention.
\end{abstract}

\section{Pendahuluan}

Pada tahun 2014, PwC melakukan survei kepada 53 negara termasuk Indonesia, mengenai perkembangan family business yang bertujuan untuk mendapatkan pemahaman tentang apa yang dipikirkan para pebisnis keluarga. Ditemukan bahwa lebih dari $95 \%$ bisnis yang ada di Indonesia dimiliki oleh keluarga. Demikian juga dengan negara-negara di Asia Tenggara, ditemukan bahwa 60 perusahaan terbuka (tbk.) merupakan perusahaan keluarga. Meskipun terlihat besar namun bila dibandingkan dengan jumlah penduduk Indonesia, jumlah pelaku usaha keluarga ini hanya berkisar di $0,2 \%$ dari total populasi Indonesia. 
Dari angka kecil tersebut, ternyata mampu memberi kontribusi kepada Pendapatan Domestik Bruto negara sebesar 25\% (PwC, 2014). Besarnya kontribusi bisnis keluarga di Indonesia sejalan dengan kecenderungan pertumbuhan yang cepat dan agresif.

Profil bisnis keluarga digambarkan sebagaimana tampak pada Gambar 1. Jika dilihat dari umur, perusahaan bisnis keluarga didominasi bisnis yang berdiri dalam rentang 20-49 tahun. Hal ini menunjukkan banyaknya perusahaan keluarga yang mampu bertahan hingga umur sebegitu lama, kemudian diikuti oleh perusahaan keluarga yang berumur dibawah 20 tahun. Meskipun baru, namun jumlah usaha yang dimulai dari keluarga jumlahnya tidak sedikit. Bila dilihat dari omzet yang didapat, didominasi oleh perusahaan dengan omzet 5-10 juta dollar. Rentang umur usaha yang panjang dan capaian omzet yang tidak sedikit dalam bisnis keluarga membuat penelitian $\mathrm{PwC}$ ini menjadi menarik. Terlebih penelitian ini mengemukakan permasalahan yang sering muncul dalam internal perusahaan keluarga seperti perekrutan karyawan (47\%), reorganisasi perusahaan (20\%), pengembangan bisnis/produk (13\%), ketersediaan keuangan (13\%), teknologi $(13 \%)$, dan pengendalian arus kas/biaya (10\%). Permasalahan dari eksternal perusahaan seperti kebijakan/peraturan pemerintah (50\%), persaingan usaha (43\%), kondisi pasar (27\%), nilai tukar (23\%), harga bahan baku (20\%), dan infrastruktur (7\%).

Perekrutan karyawan dan reorganisasi perusahaan sangat erat kaitannya dengan regenerasi dalam perusahaan terutama ketika perusahaan ingin mencari penerus bisnis keluarga. Perusahaan konsultasi bisnis, The Jakarta Consulting Group pernah melakukan suatu survei terhadap 87 perusahaan bisnis keluarga (Susanto, 2005). Dari hasil data survei, ternyata tidak semua perusahaan bisnis keluarga di Indonesia telah menyiapkan penerusnya melalui suatu perencanaan. Hanya $67,8 \%$ responden yang mengaku telah mempersiapkan penerus untuk bisisnya. Sisanya atau $32,2 \%$ ternyata belum mempersiapkan penerusnya. Data ini juga didukung dari penelitian dari PwC tahun 2014 yang menyebutkan sekitar 57\% pelaku bisnis keluarga akan mewariskan kepemilikan usahanya namun tetap melibatkan professional dalam manajemen dan juga terdapat sekitar 23\% pelaku bisnis keluarga mewariskan manajemen kepada generasi selanjutnya. Ini menunjukkan usaha keluarga yang dibangun masih melibatkan anggota keluarga dan besarnya harapan akan generasi selanjutnya untuk melanjutkan dan membangun bisnis keluarga.

Omzet (US\$s)

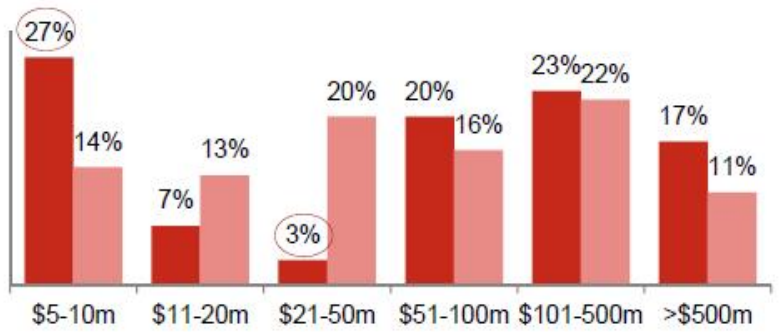

Sektor

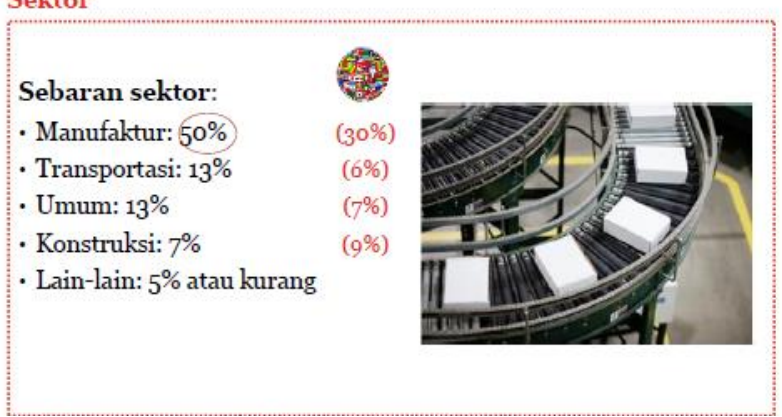

Gambar 1. Profil bisnis keluarga

Sumber: PwC, 2014
Umur perusahaan

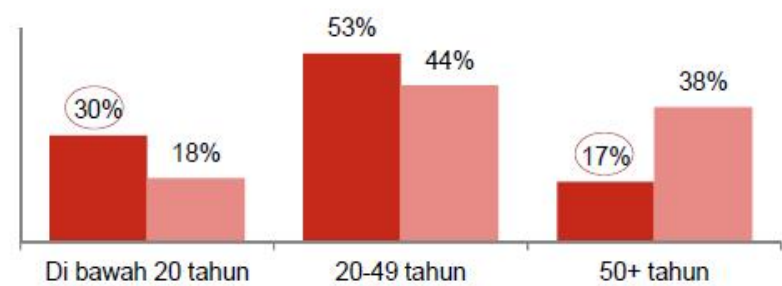

Jumlah generasi

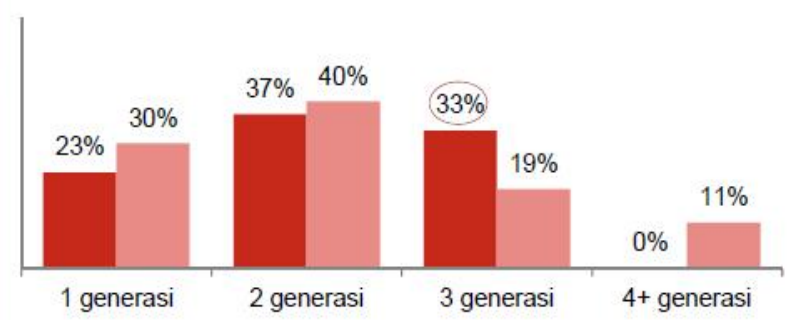

Mahasiswa Universitas Pelita Harapan khususnya di Fakultas Ekonomi dan Bisnis, sebagian besar memiliki latar belakang keluarga yang membangun bisnis. Keterlibatan keluarga secara langsung ataupun tidak dalam mengarahkan minat mahasiswa dalam membangun usaha atau terlibat dalam meneruskan usaha 
keluarga menjadi menarik untuk dilihat pada mahasiswa tersebut. Dari 10 mahasiswa yang ditanya mengenai keinginannya menjadi seorang wirausaha, sembilan mahasiswa mengatakan bahwa ia ingin menjadi wirausaha karena mereka melihat langsung sehari-hari bagaimana keluarga mereka menjalankan bisnis dan mahasiswa tersebut juga mulai dilibatkan dalam manajemen bisnis keluarga. Namun apakah meneruskan bisnis keluarga menjadi satu-satunya faktor yang membuat minatnya menjadi seorang wirausaha? Apakah minatnya itu berasal dari dalam dirinya sendiri? Penelitian ini menjadi penting dilakukan dengan rumusan masalah sekaligus tujuan penelitian untuk menganalisis pengaruh keluarga dan keyakinan dari dalam diri sendiri yang membentuk keinginan mahasiswa menjadi seorang wirausaha dimoderasi oleh keterlibatan mereka dalam bisnis keluarga. Hal ini sejalan dengan penelitian terdahulu yang menyebutkan keterlibatan keluarga yang memiliki latar belakang bisnis memberi pengaruh yang positif terhadap keinginan generasi penerus untuk memulai usaha (Saeed, Muffatto, \& Yousafzai, 2014; Prastiwi \& Agustina, 2019). Tidak hanya keluarga, lebih spesifik orang tua yang memiliki usaha juga dapat memberi pengaruh positif terhadap self efficacy generasi penerus untuk lebih yakin dalam mencoba memulai usaha (Dyer \& Handler, 1994; Zellweger, Sieger, \& Halter, 2011; Sugiantari \& Suasana, 2016).

\section{Kajian Teoritis dan Hipotesis Kewirausahaan}

Menurut Zimmerer dan Scarborough (2002) kewirausahaan adalah kemampuan seseorang untuk menghadapi risiko dengan mengembangkan kreativitas, inovasi dan keberanian dengan kerja keras, sehingga dapat menciptakan sebuah produk baru. Menurut Kuratko (2017) juga mengatakan kewirausahaan merupakan kegiatan untuk mencari, menciptakan, dan menerapkan cara kerja untuk dirujuk memberikan pelayanan dan mendapatkan keuntungan yang lebih besar. Dapat disimpulkan bahwa kewirausahaan merujuk kepada kemampuan dalam mengelola, menangani usaha, ataupun dapat menciptakan suatu hal yang baru melalui invoasi dan kreativitas, sehingga perusahaan tersebut dapat menciptakan value nya sendiri. Karakteristik seorang entrepreneurship yang disebutkan oleh Bezzina (2010) adalah pribadi yang ingin berprestasi, locus of control, tolerasi terhadap ambigutas, kepercayaan diri yang kuat, memiliki kreativitas untuk berinovasi dan berani untuk mengambil risiko.

\section{Family Business}

Menurut Diéguez-Soto, López-Delgado, and Rojo-Ramı'rez, (2015) family business adalah suatu perusahaan yang mayoritas dimiliki dan dikendalikan oleh para anggota keluarga yang sama. Mereka terlibat langsung dalam aktivitas yang terjadi di dalam perusahaan untuk mengontrol dan mengatur perusahaan, dan dipimpin langsung oleh seorang dalam anggota keluarga dari generasi pertama ataupun berikutnya. Menurut Hill (2018) terdapat empat prinsip dalam bisnis keluarga yaitu yang pertama adalah prinsip kejujuran, yaitu kejujuran di dalam internal keluarga berperan aktif dalam membangun kepercayaan antar anggota keluarga, sehingga menjadi pondasi yang kokoh dalam membangun suatu bisnis keluarga. Selain itu kejujuran di luar keluarga juga penting kejujuran terhadap negara (lewat pembayaran pajak), relasi bisnis, dan pelanggan. Kedua adalah prinsip keadilan yaitu perusahaan harus berlaku adil terhadap semua orang yang terlibat di dalam maupun di luar perusahaan. Pemberlakuan upah pegawai yang sudah sesuai dengan upah minimum regional (UMR) di wilayah tersebut, tidak sewenang-wenang terhadap pekerja yang bukan dari anggota keluarga. Ketiga adalah prinsip kelestarian lingkungan hidup, yaitu dalam menjalankan usaha bisnis keluarga, tidak menimbulkan dampak yang buruk terhadap lingkungan sekitar. Perusahaan seharusnya tidak mengambil keuntungan dari kerugian pihak lain. Keempat adalah prinsip keselamatan konsumen yaitu perusahaan harus menjamin keselamatan konsumen yang menggunakan produk/jasa yang diproduksi. Perusahaan tidak mengorbankan kesehatan ataupun keselamatan dari konsumennya untuk mendapatkan keuntungan.

\section{Keterlibatan Orang Tua Dalam Bisnis}

Keluarga dan orangtua menjadi faktor penting dalam perkembangan wirausaha. Wiratama dan Tambunan (2017) menyatakan keluarga menjadi institusi pertama dalam pembentukan sumber daya mansuia sekaligus menjadi tempat aktivitas utama seseorang. Keluarga menjadi lingkungan pertama dalam hal pembentukan mental anak untuk berwirausaha (Immanuel \& Padmalia, 2016). Orang tua yang bekerja sebagai wirausaha dapat menjadi panutan anaknya dalam berwirausaha di masa depan (Immanuel \& 
Padmalia, 2016). Di sisi lain, Sari (2015) menyampaikan peran orang tua tidak hanya membentuk karakter anak untuk menjadi wirausaha namun juga berperan dalam memberikan modal kepada anaknya. Orang tua juga mengajarkan dan memberi contoh kepada anak sejak dini untuk melihat peluang-peluang yang ada. Tidak dapat dipungkiri bahwa orang tua menjadi pendorong utama dalam terciptanya suatu usaha ataupun bisnis untuk anaknya di masa depan (Sari, 2015). Sudah jelas bahwa keluarga atau orang tua merupakan lingkungan sosialisasi yang paling penting (Antawati, 2017). Pembentukan pikiran sudah terjadi pada masa anak-anak ketika orang tua memberikan dukungan, dorongan, dan memberikan harapan yang jelas pada anaknya, sehingga mereka dapat merasa bahwa diri mereka kompeten. Dengan demikian, orang tua yang menciptakan lingkungan yang responsif dalam arti memberi mereka dukungan yang suportif akan menghasilkan anak-anak yang lebih percaya diri.

\section{Perceived Parental Entrepreneurial Rewards}

Menurut Wang, Wang, dan Chen (2018) perceived parental entrepreneurial rewards merupakan interpretasi imbalan/hadiah yang orang tua dapat terima dan dirasakan oleh anak tersebut dari pengalaman kewirausahan mereka dan kelak menjadi sukses. Termasuk di dalamnya intrinsic rewards (rasa pencapaian) dan extrinsic rewards (finansial). Contoh dari intrinsic rewards adalah perasaan yang orang tua rasakan jika anaknya kelak suatu saat sukses dalam hidupnya, maka orang tuanya akan merasakan perasaan bangga, rasa pencapaian sebagai orang tua yang sukses dalam mendidik anaknya. Contoh dari extrinsic rewards adalah ketika seorang anak membantu orang tuanya dalam hal finansial seperti membeli orang tuanya sebuah rumah atau material lain. Wang et al. (2017) mengungkapkan bahwa pembelajaran dalam hidup seseorang dapat terjadi dengan mengobservasi perilaku orang lain dan konsekuensinya. Hasil observasi/pengamatan dari konsekuensi perilaku orang lain (contohnya orang tua) memengaruhi pemilihan karir di masa depan seseorang tersebut (Wang et al., 2018). Penerus dari bisnis keluarga dapat mengantisipasi karir kewirausahaannya di masa depan dengan mengingat rewards yang dialami oleh orang tua mereka. Semakin besar perceived parental rewards yang dirasakan oleh penerusnya, maka semakin besar pula kemungkinan mereka akan meniru orang tua mereka.

\section{Entrepreneurial Intention}

Menurut Amadea dan Riana (2019) niat berwirausaha dalam seseorang dapat tumbuh dan berkembang apabila seseorang tersebut mempunyai ketertarikan pada bidang wirausaha. Ketertarikan ini biasanya muncul dikarenakan seseorang tersebut menyukai kegiatan wirausaha atau sudah tidak asing dengan kegiatan berwirausaha. Niat berwirausaha diukur dengan skala entrepreneurial intention dengan indikator seperti memilih untuk membangun usaha sendiri daripada bekerja untuk seseorang, memilih karir sebagai seorang wirausahawan, membuat suatu rencana untuk memulai suatu usaha, meningkatkan status sosial sebagai wirausaha dan mendapatkan pendapatan yang lebih baik. Menurut Amadea dan Riana (2019) niat wirausaha tersebut pun dipengaruhi oleh faktor internal dan eksternal. Faktor internal meliputi kepribadian, persepsi, motivasi, dan sikap dari seseorang tersebut. Faktor eksternal meliputi dukungan luar dari keluarga dan teman-teman atau lingkungan sekitar. Suatu tindakan yang diawali dengan niat akan memiliki awal yang lebih baik di dalam menjalankan suatu usaha dibandingkan dengan seseorang yang dari awal memang tidak memiliki niat untuk memulai suatu usaha.

\section{Self Efficacy}

Menurut Mcgee, Peterson, Mueller, dan Sequeira (2009) self efficacy mengacu pada keyakinan individu mengenai kemampuan pribadi mereka untuk mencapai pekerjaan atau serangkaian tugas tertentu. Individu dengan self-efficacy yang tinggi dalam mengerjakan tugas tertentu lebih mungkin bertahan terhadap tugas itu daripada orang-orang yang memiliki self-efficacy yang rendah. Menurut Purwanto (2014) efikasi diri adalah sebuah kepercayaan seseorang terhadap kemampuannya dalam menyelesaikan suatu pekerjaan, kepercayaan di dalam diri seseorang inilah yang menjadi motivasi berdasarkan dari apa yang mereka percayai. Menurut Antawati (2017) menjelaskan ada dua cara berbeda untuk memperkuat self efficacy seorang anak. Pertama, dihasilkan melalui dukungan, dorongan, dan pemodelan positif. Misalnya jika anak tersebut diberi tugas yang lebih menantang sejak dari usia dini dan diberi pujian atas keberhasilannya, maka anak akan memiliki self efficacy yang tinggi. Kedua, berasal dari pengalaman anak tersebut di dalam belajar untuk mengatasi situasi buruk yang dihadapain. Menurut Wibowo (2018), ada dua jenis efikasi diri dalam 
berwirausaha yaitu efikasi diri pada seseorang yang akan memulai berwirausaha dan efikasi diri ketika individu sudah berwirausaha.

\section{Pengaruh Perceived Parental Entrepreneurial Rewards terhadap Entrepreneurial Intention}

Beberapa penelitian sebelumnya mencoba mengetahui hubungan antara perceived parenal entrepreneurial rewards dan entrepreneurial intention. Salah satunya adalah penelitian Wang et al. (2018) yang mengemukakan bahwa seorang anak yang bertumbuh pada bisnis keluarga akan memiliki persepsi bahwa semakin besar ia ingin memberikan orang tuanya sebuah reward, maka akan semakin besar niat kewirausahaan yang terbentuk. Hasil penelitian yang dilakukan Intan dan Elisa (2015) dan penelitian Saeed et al. (2014) juga mengungkapkan bahwa semakin besar keinginan seorang untuk memberi reward kepada orang tuanya semakin besar juga niat kewirausahaannya.

$H_{l}$ : Terdapat pengaruh positif antara perceived parental entrepreneurial rewards terhadap entrepreneurial intention.

\section{Pengaruh Perceived Parental Entrepreneurial Rewards terhadap Entrepreneurial Self Efficacy}

Penelitian terdahulu yang ingin mengetahui hubungan antara perceived parental entrepreneurial rewards dan entrepreneurial self efficacy salah satunya adalah penelitian Wang et al. (2018) yang mengemukakan bahwa semakin besar seorang anak ingin memberikan orang tuanya sebuah reward, maka semakin tinggi pula self efficacy anak tersebut. Hasil penelitian lainnya yang dilakukan oleh Criaco, Sieger, Wennberg, Chirico, dan Minola (2017) juga menyatakan orang yang ingin memberikan orang tuanya parental reward cenderung memiliki self efficacy yang tinggi. Hasil penelitanyang sama juga didapat oleh Saeed et al. (2014) yang mengungkapkan bahwa adanya pengaruh positif antara perceived parental rewards dan self efficacy.

$\mathrm{H}_{2}$ : Terdapat pengaruh positif antara perceived parental entrepreneurial rewards terhadap entrepreneurial self efficacy.

\section{Pengaruh Family Business Involvement terhadap Entrepreneurial Intention Dimoderasi Perceived Parental Entrepreneurial Rewards}

Penelitian terdahulu dalam Wang et al. (2018) mengatakan bahwa keterlibatan bisnis keluarga mendorong upaya dan pengetahuan berwirausaha anak ketika anak memiliki perceived parental entrepreneurial rewards yang tinggi. Dapat dikatakan bahwa terdapat hubungan positif dari perceived parental entrepreneurial rewards yang dimoderasi family business involvement terhadap entrepreneurial intention. Hasil penelitian ini juga didukung oleh Saeed et al. (2014) dan juga didukung oleh Prastiwi dan Agustina (2019) yang mengungkapkan secara khusus bahwa keterlibatan bisnis keluarga memungkinkan penerus dalam bisnis keluarga untuk mengenali upaya yang diperlukan untuk mencapai hadiah wirausaha yang orang tua rasakan menyebabkan niat kewirausahaan (entrepreneurial intention) anak tersebut meningkat yang berdampak terhadap niat berwirausahanya.

$H_{3}$ : Terdapat pengaruh positif antara family business involvement memoderasi hubungan antara perceived parental entrepreneurial rewards dan entrepreneurial intention.

\section{Pengaruh Family Business Involvment terhadap Entrepreneurial Intention Dimoderasi Hubungan antara Entrepreneurial Self Efficacy}

Di dalam penelitian Wang et al. (2018) berpendapat bahwa keterlibatan bisnis keluarga akan memperkuat hubungan antara self-efficacy kewirausahaan dengan niat wirausaha. Dengan kata lain, setelah kemandirian wirausaha keluarga bisnis diaktifkan, keterlibatan bisnis keluarga akan mempercepat pembentukan niat wirausaha. Hasil penelitian yang sama yang dilakukan oleh Carr and Sequeira (2007) mengemukakan bahwa pengaruh dari orang tua memiliki positive effect terhadap self efficacy seseorang yang berpengaruh positif terhadap entrepreneurial intention orang itu. Hasil penelitian Zellweger et al. (2011) juga mengungkapkan bahwa hubungan yang terdapat antara family business involvement memoderasi entrepreneurial self efficacy dengan entrepreneurial intention memiliki hubungan yang positif.

$H_{4}$ : Terdapat pengaruh positif antara family business involvment memoderasi hubungan antara entrepreneurial self efficacy dan entrepreneurial intention. 


\section{Pengaruh Entrepreneurial Self Efficacy terhadap Entrepreneurial Intention}

Penelitian Lizar, Mangundjaya, dan Rachmawan (2015) mengemukakan bahwa jika seseorang memiliki self-efficacy yang tinggi, maka ia akan memiliki tingkat niat kewiraushaan yang tinggi juga. Hasil penelitian yang sama yang dilakukan Sugiantari dan Suasana (2016) mengungkapkan bahwa sikap kewirausahaan (self efficacy) seseorang berpengaruh positif terhadap entrepreneurial intention. Penelitian lain yang menyebutkan hasil yang sama yang dilakukan oleh Al Habib and Rahuda (2015) juga mengatakan semakin tinggi self efficacy seseorang, maka niat seorang pengusaha (entrepreneurial intention) untuk memulai bisnis baru akan lebih tinggi juga.

$H_{5}$ : Terdapat pengaruh positif antara entrepreneurial self efficacy terhadap entrepreneurial intention.

\section{Model Penelitian}

Penelitian ini membahas mengenai perceived parental entrepreneurial rewards, family business involvement, entrepreneurial self efficacy dapat memengaruhi entrepreneurial intention. Berdasarkan kajian literatur dan penelitian empiris terdahulu, maka model penelitian dapat dilihat pada Gambar 2.

\section{Metode Penelitian}

Penelitian ini menggunakan jenis penelitian deskriptif dengan analisa kuantitatif. Penelitian deskriptif bertujuan untuk melihat apakah ada hubungan antara dua variabel atau lebih, dalam suatu penelitian. Penelitian deskriptif membantu peneliti untuk 1. Mengerti karakteristik kelompok dalam situasi tertentu. 2 . Cara berpikir yang sistematis mengenai faktor-faktor dalam situasi tertentu. 3. Dapat memunculkan ide-ide baru dalam penelitian lebih lanjut, dan 4. Membantu dalam mengambil keputusan bagi peneliti maupun pengambil keputusan lainnya.

Teknik pengambilan sampel yang digunakan dalam penelitian ini adalah teknik non -probability sampling yaitu teknik pemilihan sampel yang tidak memberikan peluang yang sama atau secara tidak acak kepada setiap sampel atau setiap individu dalam populasi tersebut (Sugiyono, 2017). Metode yang dipakai dari teknik non-probability sampling adalah purposive sampling yaitu metode pemilihan sampel dengan pertimbangan tertentu. Pemilihan subjek dalam purposive sampling memberikan peluang yang tidak sama atau secara tidak acak bagi setiap individu berdasarkan beberapa kriteria. Dalam penelitian ini kriterianya adalah mahasiswa Fakultas Ekonomi dan Bisnis Universitas Pelita Harapan baik pria maupun perempuan dan sudah pernah atau sedang menjalankan bisnis. Jumlah responden yang digunakan dalam penelitian ini sebanyak 200 responden dengan menyebarkan kuesioner secara online lewat social media, e-mail dan offline. Jumlah sampel yang dipakai didapat dari jumlah indicator (20 indikator) dikalikan dengan 10 (Ghozali, 2016). Kuesioner yang terkumpul diolah menggunakan SEM PLS.

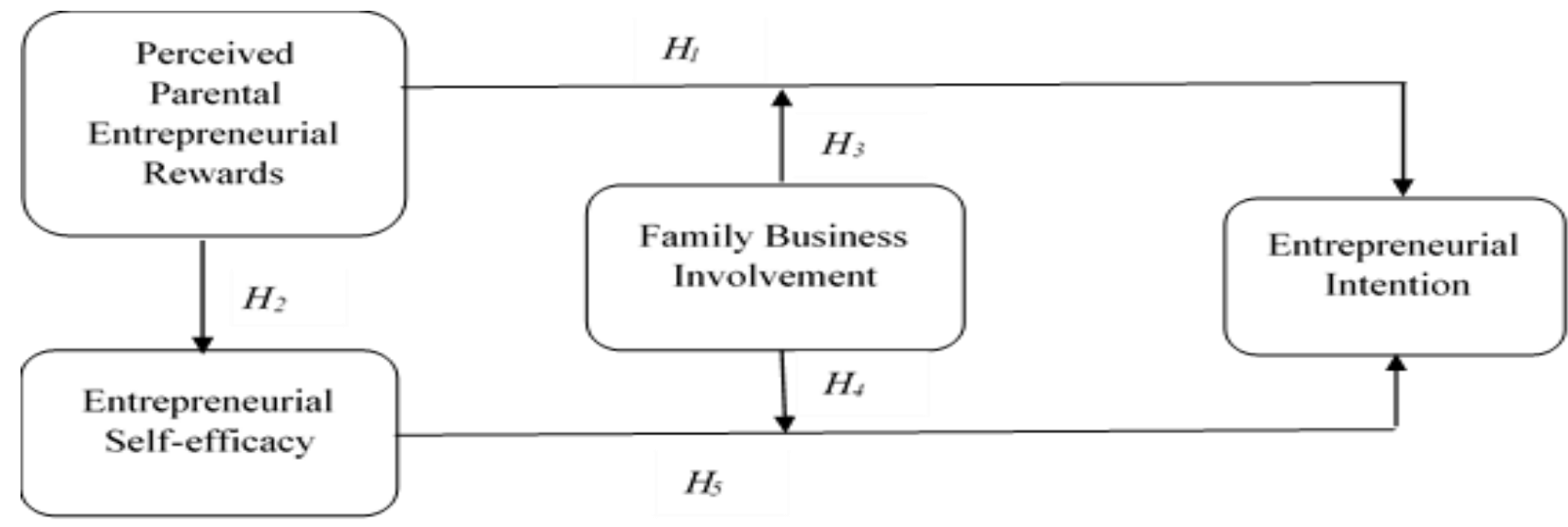

Gambar 2. Model penelitian

Sumber: Dimodifikasi dari Wang et al., 2018 
Hutabarat: Pengaruh Perceived Parental Reward, Entrepreneurial Self Efficacy, yang Dimoderasi Family Business Involvement Terhadap Entrepreneurial Intention di Universitas Pelita Harapan

Tabel 1

Defenisi Operasional

\begin{tabular}{|c|c|c|c|}
\hline Variabel & & Indikator & Sumber \\
\hline $\begin{array}{l}\text { Perceived parental } \\
\text { entrepreneurial } \\
\text { rewards }\end{array}$ & $\begin{array}{l}1 . \\
2 . \\
3 . \\
4 . \\
5 .\end{array}$ & $\begin{array}{l}\text { Ketika saya melakukan bisnis dapat membuat orang tua saya menjadi merasa tenang terhadap } \\
\text { diri mereka sendiri. } \\
\text { Ketika saya melakukan suatu bisnis membuat orang tua saya merasakan sudah mencapai suatu } \\
\text { tujuan dari diri mereka sendiri } \\
\text { Ketika saya melakukan suatu bisnis membuat orang tua saya mendapatkan sesuatu yang } \\
\text { menarik untuk dilakukan. } \\
\text { Ketika saya melakukan suatu bisnis membuat orang tua saya mendapatkan perasaan lebih } \\
\text { dihormati oleh orang lain. } \\
\text { Ketika saya melakukan suatu bisnis menjadikan orang tua saya merasa aman terhadap masa } \\
\text { depan saya. }\end{array}$ & (Wang et al., 2018) \\
\hline Self Efficacy & $\begin{array}{l}1 . \\
2 . \\
3 . \\
4 . \\
5 .\end{array}$ & $\begin{array}{l}\text { Saya selalu berusaha keras terhadap diri saya sendiri untuk mencapai hasil yang terbaik. } \\
\text { Saya merasa saya bisa menyelesaikan tugas-tugas di dalam bekerja. } \\
\text { Saya merasa saya dapat menyelesaikan masalah dengan efektif saat krisis. } \\
\text { Semangat saya bekerja berasal dari dalam diri saya sendiri. } \\
\text { Saya merasa saya dapat mengerti prosedur kerja yang saya akan lakukan. }\end{array}$ & (Hakim, 2015) \\
\hline $\begin{array}{l}\text { Family Business } \\
\text { Involvement }\end{array}$ & $\begin{array}{l}1 . \\
2 . \\
3 . \\
4 . \\
5 .\end{array}$ & $\begin{array}{l}\text { Orang tua saya menginginkan saya ikut pertemuan bisnis mereka. } \\
\text { Orang tua saya mengajarkan saya tentang bisnis keluarga. } \\
\text { Orang tua saya mendiskusikan bisnis dengan saya. } \\
\text { Orang tua saya menginginkan saya mengetahui karyawan di perusahaan mereka. } \\
\text { Orang tua saya akan mendorong saya untuk memulai bisnis saya sendiri. }\end{array}$ & $\begin{array}{l}\text { (Wang et al., 2018) } \\
\text { (Shen, Osorio, \& } \\
\text { Settles, 2017) }\end{array}$ \\
\hline $\begin{array}{l}\text { Entrepreneurial } \\
\text { Intention }\end{array}$ & & $\begin{array}{l}\text { Saya berniat melakukan bisnis di masa depan. } \\
\text { Saya lebih suka menjadi wirausahawan dalam usaha saya sendiri daripada menjadi karyawan } \\
\text { dalam suatu perusahaan/organisasi. } \\
\text { Saya sedang mempertimbangkan rencana bisnis untuk masa depan. } \\
\text { Saya merasa saya cocok untuk berwirausaha. } \\
\text { Berwirausaha menjadi pilihan saya karena dorongan dari orang tua. }\end{array}$ & $\begin{array}{l}\text { (Wang et al., 2018) } \\
\text { (Riwayati \& } \\
\text { Gunadi, 2015) }\end{array}$ \\
\hline
\end{tabular}

\section{Analisis Data dan Pembahasan}

Jumlah responden pada penelitian ini sebanyak 200 orang. Berdasarkan Tabel 1. Diketahui bahwa mayoritar responden adalah berjenis kelamin pria yaitu dengan jumlah responden 150 orang dengan persentase $75 \%$ dari seluruh respopnden, sedangkan untuk sisanya yaitu 50 orang responden adalah berjenis kelamin wanita sebesar $25 \%$.

Tabel 2

Profil Responden

\begin{tabular}{cccc}
\hline & & Jumlah Responden & Persentase \\
\hline Jenis Kelamin & Pria & 150 & $75 \%$ \\
& Wanita & 50 & $25 \%$ \\
Usia & $17-20$ tahun & 51 & $25,5 \%$ \\
& $21-23$ tahun & 137 & $68,5 \%$ \\
& $23-26$ tahun & 12 & $6 \%$ \\
Orang Tua memiliki & Di atas 26 tahun & 0 & $0 \%$ \\
bisnis & Ya & 189 & $94,5 \%$ \\
Diharapkan jadi & Tidak & 11 & $5,5 \%$ \\
penerus bisnis & Ya & 184 & $92 \%$ \\
\hline
\end{tabular}

Pada penelitian ini jumlah responden sebanyak 200 orang terdiri atas $25,5 \%$ berusia antara 17 hingga 20 tahun dengan jumlah responden 51 orang, 68,5\% berusia antara 21 hingga 23 tahun dengan jumlah 137 responden, $6 \%$ berusia 23 hingga 26 tahun dengan jumlah 12 responden, dan $0 \%$ berusia di atas 26 tahun dengan jumlah 0 responden. Pada penelitian ini jumlah responden sebanyak 200 orang terdiri atas 189 responden yang orang tuanya memiliki bisnis keluarga, dan 11 responden yang orang tuanya tidak memiliki bisnis keluarga. Pada penelitian ini jumlah responden sebanyak 200 orang terdiri atas 180 responden yang diharapkan orang tuanya meneruskan bisnis keluarga, dan 20 responden yang tidak diharapkan orang tuanya meneruskan bisnis keluarga. 


\section{Statistik Deskriptif}

Analisis statistik deskriptif digunakan untuk melihat jarak, nilai minimum, nilai maksimun, serta ratarata data. Hasil statistik deskriptif penelitian aktual dapat dilihat pada Tablel 3. Berdasarkan Tabel 3, kolom $n$ menunjukkan jumlah responden pada penelitian aktual ini yakni sejumlah 200 responden.

Nilai jarak diperoleh dari selisih nilai maksimun dengan nilai minimum masing-masing indikator. Nilai rata-rata dari jawaban responden atas keseluruhan indikator tersebut adalah 4,42 yang berarti bahwa mayoritas responden menjawab indikator tersebut dengan jawaban 'Setuju'.

\section{Hasil Analisis Structural Equation Modeling (SEM)}

Alat analisis yang digunakan untuk menganalisi data pada penelitian ini adalah SEM. Adapun perangkat lunak SEM yang digunakan pada penelitian ini adalah SmartPLS. Lebih lanjut, terdapat dua tahap dalam analisis $S E M$ yang dilakukan untuk menganalisis data yaitu uji model pengukuran (outer model) dan uji model struktural (inner model).

\section{Model Pengukuran (Outer Model)}

Dalam menguji reliabilitas dilakukan uji reliabilitas konsistensi internal dengan dua syarat yang harus dipenuhi. Syarat pertama adala nilai cronbach's alpha variabel harus lebih tinggi dari 0,6. Syarat yang kedua adalah nilai composite reliability variabel yang harus lebih tinggi dari 0,6. Tabel 4. Menunjukkan hasil uji reliabilitas variabel perceived parental reward, self efficacy, family business involvement, dan entrepreneurial intention, dengan nilai di atas aturan praktis untuk Cronbach's Alpha yaitu 0,60 (Tabel 4). Oleh karena itu dapat disimpulkan bahwa semua variabel pada penelitian ini dianggap reliabel dan dapat diandalkan.

\section{Tabel 3}

Hasil Pengujian Statistik Deskriptif

\begin{tabular}{llcccc}
\hline & $n$ & Jarak & Minimum & Maksimum & Rata-rata \\
\hline PR1 & 200 & 3 & 2 & 5 & 4,33 \\
PR2 & 200 & 4 & 1 & 5 & 4,11 \\
PR3 & 200 & 3 & 2 & 5 & 4,21 \\
PR4 & 200 & 3 & 2 & 5 & 4,215 \\
PR5 & 200 & 3 & 2 & 5 & 4,37 \\
SE1 & 200 & 3 & 2 & 5 & 4,215 \\
SE2 & 200 & 3 & 2 & 5 & 4,255 \\
SE3 & 200 & 3 & 2 & 5 & 4,26 \\
SE4 & 200 & 4 & 1 & 5 & 4,36 \\
SE5 & 200 & 3 & 2 & 5 & 4,385 \\
FB1 & 200 & 3 & 2 & 5 & 4,21 \\
FB2 & 200 & 3 & 2 & 5 & 4,245 \\
FB3 & 200 & 1 & 4 & 5 & 4,52 \\
FB4 & 200 & 3 & 2 & 5 & 4,3 \\
FB5 & 200 & 3 & 2 & 5 & 4,42 \\
EI1 & 200 & 4 & 1 & 5 & 4,23 \\
EI2 & 200 & 3 & 2 & 5 & 4,275 \\
EI3 & 200 & 4 & 1 & 5 & 4,3 \\
EI4 & 200 & 4 & 1 & 5 & 3,985 \\
EI5 & 200 & 3 & 2 & 5 & 4,27 \\
\hline
\end{tabular}

\section{Tabel 4}

Hasil Uji Reliabilitas (Cronbach's Alpha)

\begin{tabular}{lccc}
\multicolumn{1}{c}{ Variabel } & Cronbach's Alpha & $\begin{array}{c}\text { Composite } \\
\text { Reliability }\end{array}$ & Reliabilitas \\
\hline Perceived Parental Reward & 0,884 & 0,915 & Reliable \\
Self Efficacy & 0,896 & 0,923 & Reliable \\
Family Business Involvement & 0,886 & 0,917 & Reliable \\
Entrepreneurial Intention & 0,914 & 0,936 & Reliable \\
\hline
\end{tabular}

Dalam melakukan uji validitas pada model pengukuran ini persyaratan yang harus dipenuhi ada tiga. Pertama, untuk menguji validitas konvergen, nilai Average Variance Extracted (AVE) seluruh variabel 
harus lebih besar dari 0.5. Kedua, nilai outer loadings setiap indikator harus lebih besar dari 0,6. Ketiga, untuk menguji validitas diskriminan, nilai squared correlation setiap variabel lebih besar daripada cross squared correlation variabel tersebut dengan variabel lainnya (Ghozali, 2016).

Tabel 5

Hasil Uji Validitas Konvergen (AVE)

\begin{tabular}{lcc}
\hline \multicolumn{1}{c}{ Variabel } & $A V E$ & Keterangan \\
\hline Percieved Parental Reward & 0,684 & Valid \\
Self Efficacy & 0,706 & Valid \\
Family Business Involvement & 0,689 & Valid \\
Entrepreneurial Intention & 0,744 & Valid \\
\hline
\end{tabular}

Berdasarkan hasil uji validitas pada Tabel 5 diketahui bahwa untuk masing-masing indikator pada pertanyaan variabel penelitian mengelompok pada masing-masing komponen misalnya untuk perceived parental reward, self efficacy, family business involvement, dan entrepreneurial intention masing-masing memiliki angka $A V E$ lebih dari 0,5. Oleh karena itu dapat disimpulkan bahwa alat ukur pada setiap variabel dianggap valid.

Dari Tabel 5 dapat dilihat bahwa nilai $A V E$ dari seluruh variabel telah memenuhi syarat pertama validitas dalam penelitian ini yaitu di atas 0,5 (Ghozali, 2016). Selanjutnya Tabel 6 memperlihatkan bahwa seluruh indikator memiliki nilai outer loading di atas 0,6 , sehingga seluruh indikator dapat dinyatakan valid.

Tabel 6

Hasil Uji Validitas Konvergen (Outer Loadings)

\begin{tabular}{ccc}
\hline Kode Indikator & Outer Loading & Hasil \\
\hline PR1 & 0,848 & Diterima \\
PR2 & 0,871 & Diterima \\
PR3 & 0,820 & Diterima \\
PR4 & 0,793 & Diterima \\
PR5 & 0,801 & Diterima \\
SE1 & 0,796 & Diterima \\
SE2 & 0,822 & Diterima \\
SE3 & 0,859 & Diterima \\
SE4 & 0,885 & Diterima \\
SE5 & 0,837 & Diterima \\
FB1 & 0,859 & Diterima \\
FB2 & 0,808 & Diterima \\
FB3 & 0,721 & Diterima \\
FB4 & 0,855 & Diterima \\
FB5 & 0,896 & Diterima \\
EI1 & 0,847 & Diterima \\
EI2 & 0,887 & Diterima \\
EI3 & 0,823 & Diterima \\
EI4 & 0,891 & Diterima \\
EI5 & 0,863 & Diterima \\
\hline
\end{tabular}

Berdasarkan Tabel 7, yang menunjukkan hasil uji validitas diskriminan, nilai Cross loading semua variabel lebih tinggi daripada 0,5 , sehingga dapat dikatakan bahwa model pengukuran pada penelitian uji aktual ini valid (Ghozali \& Hengky, 2015). Dapat disimpulkan bahwa setiap data variabel validitas diskriminian diterima dan dapat dipergunakan untuk dilakukan uji hipotesis.

\section{Hasil Uji VIF}

Tes selanjutnya adalah menguji multikolinieritas menggunakan Variance Inflation Factor (VIF). Ambang batas untuk VIF adalah 5 yang jika indikator melebihi nilai itu, maka berarti terjadi multikolinieritas antar variabel bebas, dan menunjukkan bahwa indikator tersebut berlebihan atau tidak lagi diperlukan (Ghozali \& Hengky, 2015). Tabel 8 menunjukkan bahwa nilai VIF dari semua indikator di bawah 5, ambang batas yang berarti tidak ada multikolinieritas. 
Tabel 7

Hasil Uji Validitas Diskriminan (Cross Loading) Penelitian Aktual

\begin{tabular}{|c|c|c|c|c|}
\hline & $\begin{array}{c}\text { Entrepreneurial } \\
\text { Intention }\end{array}$ & $\begin{array}{c}\text { Family Business } \\
\text { Involvement }\end{array}$ & $\begin{array}{l}\text { Perceived Parental } \\
\text { Rewards }\end{array}$ & $\begin{array}{c}\text { Self } \\
\text { Efficacy }\end{array}$ \\
\hline$X 11$ & 0,823 & 0,870 & 0,848 & 0,905 \\
\hline$X 12$ & 0,774 & 0,818 & 0,871 & 0,785 \\
\hline$X 15$ & 0,850 & 0,808 & 0,820 & 0,755 \\
\hline$X 14$ & 0,659 & 0,787 & 0,793 & 0,796 \\
\hline$X 15$ & 0,748 & 0,678 & 0,801 & 0,710 \\
\hline$X 21$ & 0,659 & 0,787 & 0,793 & 0,796 \\
\hline$X 22$ & 0,832 & 0,790 & 0,807 & 0,822 \\
\hline$X 23$ & 0,774 & 0,786 & 0,780 & 0,859 \\
\hline$X 24$ & 0,932 & 0,842 & 0,846 & 0,885 \\
\hline$X 25$ & 0,731 & 0,853 & 0,802 & 0,837 \\
\hline$X 31$ & 0,867 & 0,859 & 0,855 & 0,803 \\
\hline$X 32$ & 0,660 & 0,808 & 0,799 & 0,801 \\
\hline$X 33$ & 0,636 & 0,721 & 0,629 & 0,613 \\
\hline$X 34$ & 0,808 & 0,855 & 0,831 & 0,884 \\
\hline$X 35$ & 0,777 & 0,896 & 0,852 & 0,884 \\
\hline$X 41$ & 0,847 & 0,768 & 0,780 & 0,809 \\
\hline$X 42$ & 0,887 & 0,856 & 0,851 & 0,820 \\
\hline$X 43$ & 0,823 & 0,859 & 0,840 & 0,905 \\
\hline$X 44$ & 0,891 & 0,740 & 0,809 & 0,779 \\
\hline$X 45$ & 0,863 & 0,690 & 0,739 & 0,723 \\
\hline
\end{tabular}

Tabel 8

\section{Hasil VIF}

\begin{tabular}{lccc}
\hline & VIF & & VIF \\
\hline$X_{11}$ & 2,353 & $X_{31}$ & 2,329 \\
$X_{12}$ & 3,084 & $X_{32}$ & 3,013 \\
$X_{13}$ & 2,403 & $X_{33}$ & 1,762 \\
$X_{14}$ & 2,037 & $X_{34}$ & 2,359 \\
$X_{15}$ & 2,047 & $X_{35}$ & 4,044 \\
$X_{21}$ & 2,301 & $X_{41}$ & 2,534 \\
$X_{22}$ & 2,677 & $X_{42}$ & 3,239 \\
$X_{23}$ & 2,920 & $X_{43}$ & 2,173 \\
$X_{24}$ & 2,865 & $X_{44}$ & 3,705 \\
$X_{25}$ & 2,908 & $X_{45}$ & 2,987 \\
\hline
\end{tabular}

\section{Model Struktural (Inner Model)}

Setelah melakukan uji model pengukuran selanjutnya dilakukan uji model struktural. Pengujian hipotesis menggunakan dua kriteria untuk menentukan diterima atau ditolaknya hipotesis. Kriteria yang pertama adalah $t$-statistics atau nilai kritis, di mana hipotesis diterima apabila hipotesis memiliki nilai kritis (t-statistisc) lebih dari 1,972 atau dengan menggunakan kriteria kedua yaitu $p$-value, di mana hipotesis diterima apabila hipotesis memiliki $p$-value kurang dari 0,05. Hasil pengujian hipotesis dipaparkan pada Tabel 9.

Berdasarkan Tabel 9 dapat dilihat bahwa semua hipotesis pada penelitian ini didukung dan diterima. Hal ini disimpulkan berdasarkan nilai $t$-statistics masing-masing hipotesis. Apabila nilai $t$-statistics pada hubungan antar variabel lebih dari 1,972 > t-table $(1,96)$ dan $p$-value bernilai kurang dari 0,05 , maka hipotesis dapat diterima dan didukung.

Berdasarkan pengujian model struktural yang dilakukan, hipotesis pertama memiliki nilai kritis $(t$ statistics) sebesar 4,740>t-table $(1,96)$ dengan $p$-value 0,000 . Hipotesis kedua memiliki nilai kritis $(t$ statistics) sebesar 181,857 dengan p-value 0,000. Hipotesis ketiga memiliki nilai kritis (t-statistics) sebesar $3,197>t$-table $(1,96)$ dengan $p$-value 0,021 . Hipotesis keempat memiliki nilai kritis ( $t$-statistics) sebesar $3,123>t$-table (1.96) dengan $p$-value 0,002. Hipotesis kelima memiliki nilai kritis ( $t$-statistics) sebesar 
$6,275>$ t-table $(1,96)$ dengan p-value 0,000. Hasil pengujian model pengukuran dan model struktural penelitian ini ditunjukkan oleh Gambar 3.

Tabel 9

Hasil Uji Model Struktural (Hipotesis)

\begin{tabular}{|c|c|c|c|c|c|}
\hline Hipotesis & Hubungan Variabel & $\begin{array}{l}\text { Path } \\
\text { Coeff }\end{array}$ & $\begin{array}{c}t- \\
\text { statistic }\end{array}$ & $\begin{array}{c}P \\
\text { value }\end{array}$ & Kesimpulan \\
\hline$H_{l}$ & $\begin{array}{l}\text { Perceived parental entrepreneurial rewards berpengaruh } \\
\text { positif terhadap entrepreneurial intention. }\end{array}$ & 0,494 & 4,740 & 0,000 & Didukung \\
\hline $\mathrm{H}_{2}$ & $\begin{array}{l}\text { Perceived parental entrepreneurial rewards memiliki } \\
\text { pengaruh positif terhadap entrepreneural self efficacy. }\end{array}$ & 0,959 & 181,857 & 0,000 & Didukung \\
\hline $\mathrm{H}_{3}$ & $\begin{array}{l}\text { Family business involvement memoderasi hubungan } \\
\text { perceived parental entrepreneural rewards dan } \\
\text { entrepreneural intention. }\end{array}$ & 0,185 & 3,197 & 0,001 & Didukung \\
\hline$H_{4}$ & $\begin{array}{l}\text { Family business involvement memoderasi hubungan } \\
\text { antara entrepreneural self efficacy dan entrepreneural } \\
\text { intention. }\end{array}$ & $-0,224$ & 3,123 & 0,002 & Didukung \\
\hline $\mathrm{H}_{5}$ & $\begin{array}{l}\text { Entrepreneural self efficacy memiliki pengaruh positif } \\
\text { terhadap entrepreneural intention. }\end{array}$ & 0,611 & 6,275 & 0,000 & Didukung \\
\hline
\end{tabular}

\section{R Square}

Dalam menilai suatu kontruk penelitian, model penelitian direpresentasikan dengan nilai $R$ square $\left(R^{2}\right)$. Alasan digunakannya nilai $R^{2}$ dan bukan Adjusted $R^{2}$ adalah karena hanya ingin melihat seberapa besar pengaruh variabel bebas terhadap variabel terikat sedangkan Adjusted $R^{2}$ melihat seberapa besar pengaruh ketika adanya penambahan satu variabel.

Hasil $R^{2}$ menjadikan suatu model penelitian dapat dipercaya atau tidak (Ghozali, 2016). Seperti yang dilihat pada Tabel 10 nilai $R^{2}$ adalah 0,905 yang berarti bahwa 90,5\% seluruh variabel independen memengaruhi variabel terikat, sedangkan sisa $9,5 \%$ dipengaruhi oleh variabel lainnya yang tidak diteliti.

Tabel 10

$R^{2}$ Tabel

\begin{tabular}{lc}
\hline \multicolumn{1}{c}{ Variabel } & $R^{2}$ \\
\hline Etrepreneural intention & 0,905 \\
Self efficacy & 0,920 \\
\hline
\end{tabular}

\section{Pembahasan}

Pada penelitian ini analisis data aktual dilakukan dengan menggunakan data dari 200 responden. Hipotesis 1 menyebutkan bahwa perceived parental entrepreneurial rewards berpengaruh positif terhadap entrepreneurial intention. Berdasarkan Tabel 9 diketahui hipotesis pertama memiliki $t$-statistics sebesar 4,740 dan $p$-value 0,000 . Tolok ukur atau batas yang telah ditentukan adalah apabila hipotesis memiliki nilai $t$-statistics di atas 1.972 dan memiliki p-value kurang dari 0,05, maka hipotesis didukung. Dengan nilai path coefficient sebesar 0,494 berarti perceived parental entrepreneurial rewards memberi pengaruh yang signifikan sebesar $49,4 \%$ terhadap terbentuknya entrepreneurial intention pada mahasiswa Universitas Pelita Harapan. Dengan kata lain keinginan mahasiswa untuk menjadi seorang wirausaha dilatarbelakangi oleh penghargaan yang ingin diberikan kepada orang tua mereka sebesar 49,4\%. Hasil ini sejalan dengan penelitian yang dilakukan oleh Wang et al. (2018), Intan dan Elisa (2015), dan Saeed et al. (2014).

Hipotesis 2 menyebutkan bahwa entrepreneurial self-efficacy memediasi hubungan antara perceived parental entrepreneurial rewards dan entrepreneurial intention. Berdasarkan hasil pada Tabel 9, hipotesis kedua memiliki $t$-statistics sebesar 181,857 dan p-value 0,000. Tolak ukur atau batas yang telah ditentukan adalah apabila hipotesis memiliki nilai $t$-statistics di atas 1,972 dan memiliki $p$-value kurang dari 0,05, maka hipotesis didukung. Entrepreneurial intention merupakan tekad atau suatu keinginan untuk berjuang menjadi pengusaha. Dengan nilai path coefficient sebesar 0,959 menunjukkan perceived parental rewards berpengaruh kepada entrepreneurial self efficacy sebesar 95,9\%. Atau dengan kata lain, keyakinan mahasiswa 
untuk menjadi seorang wirausaha dilatarbelakangi oleh pemberian penghargaan kepada orang tua sebesar 95,9\%. Hasil ini sesuai dengan penelitian yang dilakukan oleh Wang et al. (2018), Criaco et al. (2017), Saeed et al. (2014).

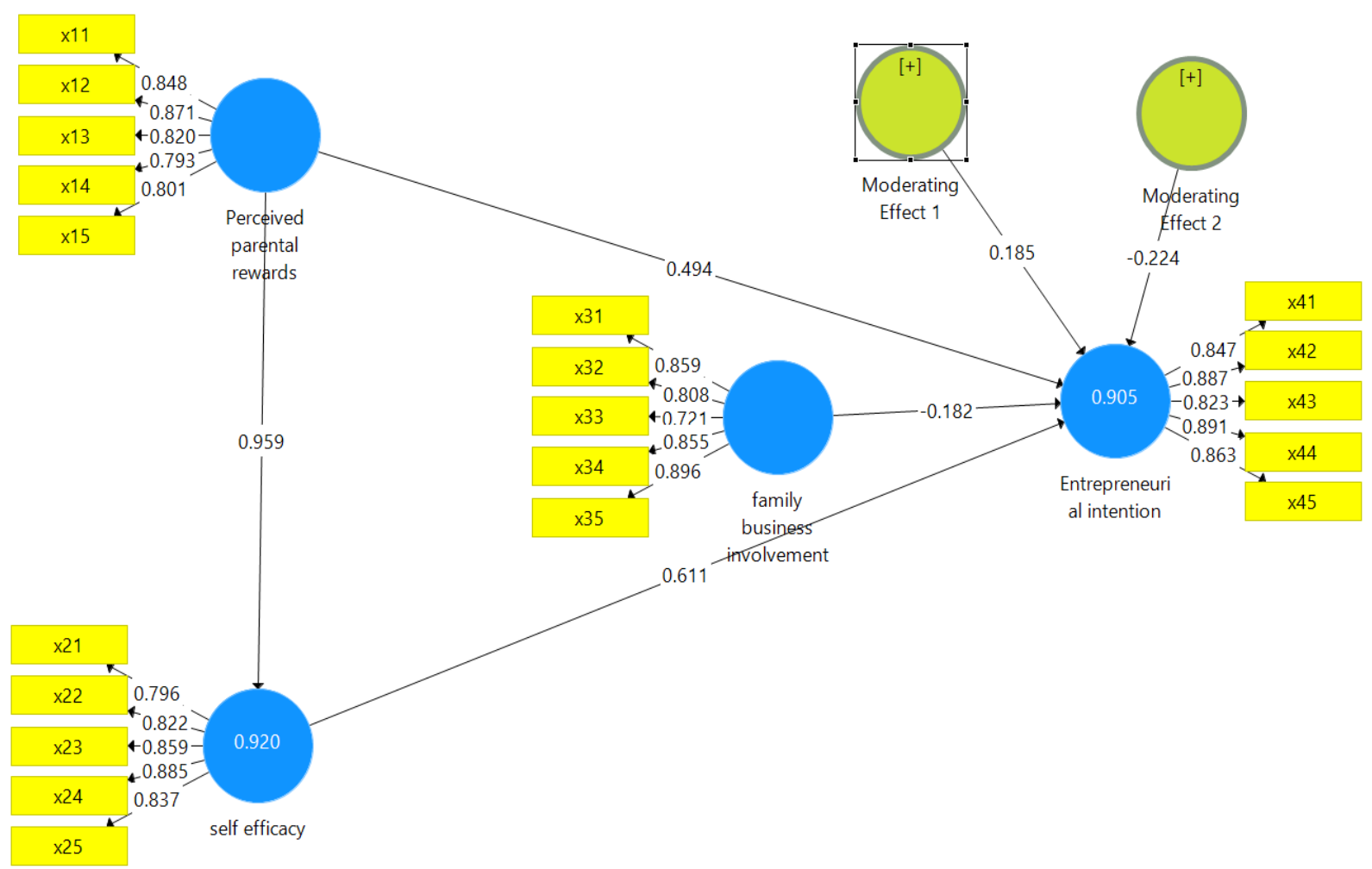

\section{Gambar 3. Model pengukuran dan model struktural}

Hipotesis 3 menyebutkan bahwa family business involvement memperkuat atau memperlemah hubungan antara perceived parental entrepreneurial rewards dan entrepreneurial intention. Berdasarkan Tabel 9, hipotesis ketiga memiliki $t$-statistics sebesar 3,197 dan $p$-value 0,001. Tolak ukur atau batas yang telah ditentukan adalah apabila hipotesis memiliki nilai $t$-statistics di atas 1.972 dan memiliki nilai $p$-value kurang dari 0,05, maka hipotesis didukung. Nilai $t$-statistics hipotesis ketiga lebih dari 1,972, yaitu 3,197> 1,972 dan $p$-value hipotesis ketiga kurang dari 0,05 , yaitu $0,001<0.05$ maka hipotesis ketiga dinyatakan diterima dan didukung. Family business involvement sendiri merupakan keterlibatan antara orang tua dan anak yang menginginkan sang anak meneruskan suatu bisnis keluarga yang sudah dikelola cukup lama. Dari hasil penelitian ini juga ditunjukkan bahwa nilai path coefficient hipotesis ini sebesar 0,185 yang berarti variabel keterlibatan mahasiswa dalam bisnis keluarga memberi pengaruh yang memperkuat keinginan mahasiswa untuk menjadi seorang wirausaha yang dilatarbelakangi oleh keingian pemberian penghargaan kepada orang tua sebesar 18,5\%. Penelitian ini mendukung hasil penelitian terdahulu (Wang et al., 2018; Saeed et al., 2014; Prastiwi \& Agustina, 2019).

Hipotesis 4 menyebutkan bahwa family business involvement memoderasi hubungan antara entrepreneurial self-efficacy dan entrepreneurial intention. Berdasarkan Tabel 9, hipotesis keempat memiliki nilai $t$ statistics sebesar 3,123 dan p-value 0,002. Tolak ukur atau batas yang telah ditentukan adalah apabila hipotesis memiliki nilai $t$-statistics di atas 1,972 dan memiliki nilai $p$-value kurang dari 0,05, maka hipotesis didukung. Dengan nilai path coefficient sebesar $-0,224$ berarti keterlibatan mahasiswa dalam usaha keluarga justru memperlemah keinginan mahasiswa untuk menjadi seorang wirausaha yang dilatarbelakangi oleh keyakinan dari dalam diri sendiri untuk mampu menjadi seorang wirausaha sebesar 22,4\%. Hasil ini berbeda dari hasil penelitian terdahulu yang dilakukan oleh Wang et al. (2018), Carr and Sequira (2007) dan Zellweger et al. (2011).

Hipotesis 5 menyebutkan bahwa entrepreneural self efficacy memiliki pengaruh positif terhadap entrepreneural intention. Berdasarkan Tabel 9, hipotesis kelima memiliki nilai $t$-statistics sebesar 6,275 dan p-value 0,000 Tolak ukur atau batas yang telah ditentukan adalah apabila hipotesis memiliki nilai t-statistics 
di atas 1,972 dan memiliki nilai p-value kurang dari 0,05, maka hipotesis diterima. Dengan nilai path coefficient sebesar 0,611 menunjukkan bahwa keyakinan menjadi seorang wirausaha dipengaruhi oleh keyakinan dari dalam diri sendiri untuk mampu menjadi seorang wirausaha sebesar $61,1 \%$. Hasil ini didukung oleh penelitian terdahulu dari Lizar et al. (2015), Suagiantari dan Suasana (2016), dan Al Habib dan Rahuda (2015).

\section{Simpulan, Keterbatasan, dan Saran Simpulan}

Pada simpulan kali ini dilakukan untuk menjawab perumusan masalah yang diajukan dalam penelitian ini. Berdasarkan hasil dan pembahasan yang telah dilakukan sebelumnya dengan mengacu pada hipotesis yang dirumuskan, dapat disimpulkan bahwa:

1. Perceived parental entrepreneurial rewards berpengaruh positif terhadap entrepreneurial intention. Keinginan mahasiswa Fakultas Ekonomi dan Bisnis Universitas Pelita Harapan untuk menjadi seorang wirausaha lebih dilatarbelakangi oleh keinginan mereka membahagiakan orang tua mereka terutama oleh mahasiswa yang memiliki keluarga dengan latar belakang pengusaha dan mulai dilibatkan dalam bisnis keluarga.

2. Perceived parental entrepreneurial rewards memiliki pengaruh positif terhadap entrepreneurial self efficacy. Mahasiswa merasa senang jika orang tua mereka merasa aman ketika tahu bahwa anak mereka/mahasiswa ikut terlibat dalam bisnis keluarga atau sudah mulai menjalankan bisnis. Hal ini didukung oleh keyakinan mahasiswa akan pengetahuan mereka akan prosedur kerja yang sudah mereka lihat dan alami ketika membantu orang tua mereka dalam menjalankan bisnis.

3. Family business involvement memoderasi hubungan perceived parental entrepreneurial rewards dan entrepreneurial intention. Keterlibatan orang tua dan keluarga membantu meyakinkan mahasiswa untuk memulai bisnis dengan cara melibatkan dan mendiskusikan semua kejadian dalam bisnis keluarga dengan anggota keluarga lain termasuk mahasiswa.

4. Family Business Involvement memoderasi hubungan antara Entrepreneuiral Self Efficacy dan Entrepreneurial Intention. Keterlibatan mahasiswa dalam bisnis keluarga justru kurang memberi pengaruh yang signifikan kepada keyakinan diri sendiri atas kemampuannya menjadi seorang wirausaha.

5. Entrepreneurial self efficacy memiliki pengaruh positif terhadap entrepreneurial intention. Keyakinan akan diri mahasiswa dalam menjalankan bisnis dibutuhkan kontribusi tidak hanya dari keluarga namun juga pengetahuan mahasiswa dalam mengenal usaha atau industri yang akan dijalankan.

\section{Keterbatasan}

Keterbatasan pada penelitian ini adalah sampel dalam penelitian ini hanya mahasiswa Universitas Pelita Harapan khusus Fakultas Ekonomi dan Bisnis yang sudah pernah dan atau sedang memulai usaha sendiri. Keinginan berwirausaha berlaku bagi semua mahasiswa dengan beragam latar belakang, sehingga perlu juga dilakukan penelitian untuk melihat keinginan berwirausaha mahasiswa yang belum pernah memulai usaha dengan beragam latar belakang, baik latar belakang pengusaha maupun bukan.

\section{Saran}

Untuk penelitian selanjutnya perlu dimasukkan faktor pengetahuan kewirausahaan dan budaya lokal setempat yang mana masih banyak budaya yang mengutamakan anaknya menjadi Pegawai Negeri Sipil atau bekerja untuk orang lain dibanding membuka usaha. Bagi institusi pendidikan seperti Universitas Pelita Harapan, upaya meningkatkan keinginan mahasiswa menjadi seorang wirausaha dapat dilakukan dengan memberikan seminar secara periodik dan berkesinambungan yang berhubungan dengan pentingnya perasaan orangtua kepada kesuksesan para mahasiswa dan bagaimana memulai usaha. Hal tersebut dapat menjadi pemicu atau pecut bagi mahasiswa untuk berhasil dalam menjalankan bisnis. Seminar yang dilakukan ini dapat memberi sebuah motivasi kepada mahasiswa tentang pentingnya perasaan orangtua yang akan bangga dan bahagia apabila melihat anaknya mencapai kesuksesan. Di tambah lagi dengan adanya pelajaran tentang pengelolaan bisnis keluarga yang dapat membuat mahasiswa merasa menjadi seorang yang diharapkan untuk menjadi pengusaha yang sukses. Dalam meningkatkan efikasi diri, mahasiswa Universitas Pelita Harapan dapat diberikan pengalaman-pengalaman berorganisasi yang membentuk karakter dan skill para mahasiswa dalam hal berorganisasi dan kewirausahaaan. 


\section{Referensi}

Al Habib, M. F., \& Rahuda, I. K. (2015). Pengaruh efikasi diri, kebutuhan akan prestasi dan berwirausaha mahasiswa. E-Jurnal Manajemen, 4(9), 2618-2646.

Amadea, P. T., \& Riana, I. G. (2019). Pengaruh motivasi berwirausaha, pengendalian diri, dan lingkungan keluarga terhadap niat berwirausaha. E-Jurnal Manajemen, 9(4), 1594-1613. https://doi.org/ 10.24843/EJMUNUD.2020.v09.i04.p18

Antawati, D. I. (2017). Peran orangtua dalam menumbuhkan intensi berwirausaha pada anak. Ekspektra, 1(1), 46-54. https://doi.org/10.25139/ekt.v1i1.87

Bezzina, F. (2010). Characteristics of the Maltese entrepreneur. International Journal of Arts and Sciences 3(7), 292-312.

Carr, J. C., \& Sequeira, J. M. (2007). Prior family business exposure as intergenerational influence and entrepreneurial intent: A theory of planned behavior approach, Journal of Business Research 60(10), 1090-1098. https://doi.org/10.1016/j.jbusres.2006. 12.016

Criaco, G., Sieger, P., Wennberg, K., Chirico, F., \& Minola, T. (2017). Parents' performance in entrepreneurship as a "double-edged sword " for the intergenerational transmission of entrepreneurship. Small Business Economics 49 (4), 841-864 https:// doi.org/10.1007/s11187-017-9854-x

Diéguez-Soto, J., López-Delgado, P., \& Rojo-Ramı' rez, A. (2015). Identifying and classifying family businesses. Review of Managerial Science, 9(2), 603-634. https://doi. org/10.1007/s11846-014-0128-6

Dyer, J. W. G., \& Handler, W. (1994). Entrepreneurship and family business: Exploring the connections. Entrepreneurship: Theory \& Practice, 19(1), 71-83.

Ghozali, I. (2016). Aplikasi analisis multivariate dengan Program IBM SPSS 23. Edisi 8. Semarang: Badan Penerbit Universitas Diponegoro.

Ghozali, I., \& Hengky, L. (2015). Konsep, teknik dan aplikasi menggunakan Program Smart PLS 3.0. Semarang: Universitas Diponegoro.

Hakim, M. A. L. (2015). Peran persepsi manajamen perusahaan terhadap self efficacy karyawan PT Cendana Teknika Utama. Unika Soegijapranata, 151, 10-17. https:// doi.org/10.1145/3132847. 3132886

Hill, A. (2018). Just business: Christian ethics for the marketplace. Downers Grove, IL: InterVarsity Press.

Immanuel, D. M., \& Padmalia, M. (2016). Identifikasi peranan orang tua wirausaha dalam pembentukan karakter entrepreneurial spirit dan keberlangsungan business project mahasiswa Universitas Ciputra. Jurnal Ekonomi dan Bisnis, 19(2), 263-280. https://doi.org/https://doi.org/10.24914/jeb.v19i2.557

Intan, H., \& Elisa. (2015). Analisis alasan berwirausaha terhadap keputusan pelaksanaan bisnis sampingan ( Pada pemilik bisnis di kawasan sekitar Kambang Iwak dan Jalan Balap Sepeda Pom-X Palembang). Jurnal Manajemen \& Bisnis Sriwijaya, 13(2), 1-12.

Kuratko, D. F. (2017). Corporate entrepreneurship \& innovation: Today's leadership challenge. In G. Ahmetoglu, T. Chamorro-Premuzic, B. Klinger, \& T. Karcisky (Eds.), The Wiley handbook of entrepreneurship (pp. 293-311). John Wiley \& Sons. https //doi.org/10.1002/9781118970812.ch14

Lizar, A. A., Mangundjaya, W. L., \& Rachmawan, A. (2015). The role of psychological capital and psychological empowerment on individual readiness for change. The Journal of Developing Areas, 49(5), 343-352 https://doi.org/10.1353/jda.2015.0063

Mcgee, J. E., Peterson, M., Mueller, S. L., \& Sequeira, J. M. (2009). Entrepreneur self-efficacy: Refining the measure. Entrepreneurship Theory and Practice 33(4), 965-988. https:// doi.org/10.1111/j.15406520.2009.00304.x

Prastiwi, I. A., \& Agustina, T. S. (2019). Latar belakang keluarga wirausaha dan niat untuk berwirausaha. Prosiding FRMA 2019, 578-589.

Purwanto, F. X. A. (2014). Pengaruh efikasi diri, pengetahuan kewirausahaan, dan motivasi berwirausaha terhadap minat mahasiswa berwirausaha (Studi pada mahasiswa Diploma Pelayaran Universitas Hang Tuah Surabaya). Jurnal Aplikasi Pelayaran dan Kepelabuhan, 6(2), 104-127.

PwC. (2014). Survey bisnis keluarga 2014, (November). Retrieved April 2020 from PwC: https://www.pwc.com/id/en/publications/assets/indonesia-report-family-business-su rvey-2014.pdf

Riwayati, A., \& Gunadi, T. (2015). Pengaruh efikasi diri terhadap minat berwirausaha siswa sekolah menengah program keahlian rekayasa perangkat teknologi informasi dan komunikasi. Coopetiiton, $6(1), 39-50$.

Saeed, S., Muffatto, M., \& Yousafzai, S. Y. (2014). Exploring intergenerational influence on entrepreneu- 
rial intention: The mediating role of perceived desirability and perceived feasibility. International Journal of Entrepreneurship and Innovation Management 18(2/3), 134-153. https://doi.org/10.1504/ IJEIM.2014.062877

Sari, A. K. (2015). Pengaruh peran orang tua, guru, dan self-efficacy terhadap kesiapan berwirausaha siswa SMK Muhammadyah 1 Bantul Kompetensi Keahlian Audio Video Kelas XII. Lumbung Pustaka Universitas Negeri Yogyakarta. Retrieved from https://eprints.uny.ac.id/19901/

Shen, T., Osorio, A. E., \& Settles, A. (2017). Does family support matter? The iinfluence of support factors on entrepreneurial attitudes and intentions of college students. Academy of Entrepreneurship Journal, 23(1), 24-43.

Sugiantari, N. W. A., \& Suasana, I. G. A. G. (2016). Kajian empiris penentu niat berwirausaha pada mahasiswa. E-Jurnal Manajemen, 5(6), 3364-3391.

Sugiyono. (2017). Metode penelitian kuantitatif, kualitatif, dan R\&D. Bandung: CV. Alfabeta.

Susanto, A. B. (2005), World class family business: Membangun perusahaan keluarga berkelas dunia. Jakarta: Quantum Bisnis \& Manajemen.

Wang, D., Wang, L., \& Chen, L. (2018). Unlocking the influence of family business exposure on entrepreneurial intentions. International Entrepreneurship and Management Journal, 14, 951-974. https://doi.org/10.1007/s11365-017-0475-2

Wibowo, S. T. (2018). Konsep diri dan efikasi diri berwirausaha pada pemilik usaha ritel mikro kecil menengah di Jogjakarta. Jurnal Manajemen dan Kewirausahaan, 4(2), 1-82.

Wiratama, D. Y., \& Tambunan, F. (2017). Pengaruh peran keluarga terhadap keberhasilan wirausaha di Kelurahan Helvetia Tengah, Medan. Prosiding Seminar Hilirisasi Penelitian Untuk Kesejahteraan Masyarakat Lembaga Penelitian Universitas Negeri Medan, pp. 720-732.

Zellweger, T., Sieger, P., \& Halter, F. (2011). Should I stay or should I go? Career choice Intention of Student with family business background. Journal of Business Venturing, 26(5), 521-536. https://doi.org/10.1016/j.jbusvent.2010.04.001

Zimmerer, T. W., \& Scarborough, N. M. (2002). Essentials of entrepreneurship and small business management. Third Edition. New Jersey, NJ: Pearson. 